\title{
Extracellular bacterial production of doped magnetite nanoparticles
}

Link to publication record in Manchester Research Explorer

\section{Citation for published version (APA):}

Pearce, C. I., Pattrick, R. A. D., Coker, V. S., Telling, N. D., van der Laan, G., Lloyd, J. R., \& O'Brien, P. (Ed.) (2013). Extracellular bacterial production of doped magnetite nanoparticles. In Nanoscience: Volume 1: Nanostructures through Chemistry (1 ed., Vol. 1, pp. 102-115). Royal Society of Chemistry.

\section{Published in:}

Nanoscience: Volume 1: Nanostructures through Chemistry

\section{Citing this paper}

Please note that where the full-text provided on Manchester Research Explorer is the Author Accepted Manuscript or Proof version this may differ from the final Published version. If citing, it is advised that you check and use the publisher's definitive version.

\section{General rights}

Copyright and moral rights for the publications made accessible in the Research Explorer are retained by the authors and/or other copyright owners and it is a condition of accessing publications that users recognise and abide by the legal requirements associated with these rights.

\section{Takedown policy}

If you believe that this document breaches copyright please refer to the University of Manchester's Takedown Procedures [http://man.ac.uk/04Y6Bo] or contact uml.scholarlycommunications@manchester.ac.uk providing relevant details, so we can investigate your claim.

\section{OPEN ACCESS}




\title{
Extracellular bacterial production of doped magnetite nanoparticles
}

\author{
Richard A D Pattrick, ${ }^{* a}$ Victoria S Coker, ${ }^{a}$ Carolyn I Pearce, ${ }^{b}$ \\ Neil D Telling, ${ }^{c}$ Gerrit van der Laan ${ }^{a, d}$ and Jonathan R Lloyd ${ }^{a}$ \\ DOI: $10.1039 / 9781849734844-00102$
}

\begin{abstract}
Microorganisms have been producing nanoparticles for billions of years and by controlling and tuning this productivity they have the potential to provide novel materials using environmentally friendly manufacturing pathways. Metal-reducing bacteria are a particularly fertile source of nanoparticles and their reduction of $\mathrm{Fe}$ (III) oxides leads to the formation of ferrite spinel nanoparticles, especially magnetite, $\mathrm{Fe}_{3} \mathrm{O}_{4}$. The high yields produced by extracellular biomineralising processes make them commercially attractive, and the production of these bionano ferrite spinels can be tuned by doping the precursor $\mathrm{Fe}(\mathrm{III})$ phase with $\mathrm{Co}, \mathrm{Ni}, \mathrm{Zn}$, $\mathrm{Mn}$ and $\mathrm{V}$. The oxidation state of the cations and the sites of substitution are determined by X-ray absorption spectroscopy (XAS), especially by examination of metal $L$-edge spectra and X-ray magnetic circular dichroism (XMCD). Vanadium substitution in bionano ferrite spinels is revealed for the first time, and substitution in the octahedral site as V(III) confirmed. Bionanomagnetite is shown to be effective in the remediation of azo dyes with the complete breakdown of Remazol Black B to colourless amines and acids. XMCD shows this to involve oxidation of the surface $\mathrm{Fe}(\mathrm{III})$ and the potential for regeneration of the nanoparticles.
\end{abstract}

\section{Introduction}

The current search for functional nanomaterials is unrelenting with a wide variety of inorganic pathways being employed and investigated. However, it is becoming clear that microbial approaches, exploiting a wide and relatively untapped genetic diversity that has developed over $>3.5$ billion years of evolution, offers potentially clean and scalable biotechnological alternatives. ${ }^{1}$ Physiological processes including redox transformations linked to microbial respiration of metals, detoxification reactions, and the bioproduction of biological ligands that can precipitate metals in highly reactive compartments in or around the microbial cell, can all play their part in nanoparticle biosynthesis reactions. For a recent overview of some of the products produced by such processes, which include bionanoparticles developed for catalysis, antimicrobial, photonic and magnetic applications, the reader is referred to ${ }^{2,3}$ and references therein. This review focuses on the microbial production of iron-based magnetic nanoparticles, which can be

\footnotetext{
${ }^{a}$ Williamson Research Centre for Molecular Environmental Science and School of Earth, Atmospheric and Environmental Sciences, University of Manchester, Manchester, M13 9PL, UK. E-mail: richard.pattrick@manchester.ac.uk

${ }^{b}$ Pacific and Northwest National Laboratory, P.O. Box 999, Richland, WA 99352, USA

${ }^{c}$ Institute for Science \& Technology in Medicine, Keele University, Guy Hilton Research Centre, Thornburrow Drive, Hartshill, Stoke-on-Trent ST4 7QB, UK

${ }^{d}$ Diamond Light Source, Harwell Science and Innovation Campus, Didcot, Oxfordshire, $O X 110 D E U K$
} 
produced either internally as "magnetosomes" which form as an integiay Online part of the cell in a very controlled metabolic environment, or as a result of extracellular process where the production of nanoparticles is a by-product of respiratory processes, in this case the "dissimilatory" reduction of ferric iron minerals. ${ }^{4-6}$ Although first recognised in the proteobacteria, the ability of microorganisms to produce intracellular Fe-based magnetotactic nanoparticles may well have evolved several times in the evolutionary record, ${ }^{5}$ and examples of extracellular production of nanoparticles by dissimilatory iron reduction occur in many archaeal and bacterial genera, catalysed by distinct mechanisms that are genera specific. ${ }^{6-8}$

The intracellular magnetosomes found in magnetotactic bacteria which occupy a range of aquatic environments, have been studied extensively. The nanoparticles classically form chains of regular single crystals of magnetite $\left(\mathrm{Fe}_{3} \mathrm{O}_{4}\right)$ or less regular crystals of greigite $\left(\mathrm{Fe}_{3} \mathrm{~S}_{4}\right){ }^{9}{ }^{9,10}$ These are contained within the cell and the $30-150 \mu \mathrm{m}$ magnetite particles form monodisperse, perfect cubic $\{100\}$, octahedral $\{111\}$ and dodecahedral $\{110\}$ forms, or hybrids of these shapes such as cubooctahedral habits ${ }^{11,12}$ and therefore present the potential for the production of high quality nanocrystals (Fig. 1).

Furthermore, a relationship between bacterial species and crystal shape, and the successful doping of the magnetite with $1.4 \% \mathrm{Co}^{13,14}$ gives the prospect of customised nanoparticles. However, despite their biological and intrinsic interest, the problem of exploiting magnetosomes is the fastidious nature of these fascinating (but often hard to cultivate) organisms, and the challenge of producing enough biomass to produce even milligrams of material.

In terms of volume, it is the extracellular production of nanoparticles by bacteria that would seem to have most commercial potential. ${ }^{15}$ Over the past decades, our knowledge of extracellular biomineralising processes and microorganisms has grown in response to our appreciation of their role in elemental cycling (discussed at length in ${ }^{16,17}$ ). Passive interactions of cells with their geochemical environment causes biomineralisation either by metal sorption onto charged cell walls and extracellular layers, resulting in heterogeneous nucleation and mineral precipitation, or by microbial metabolism changing the local redox conditions that results in the expulsion of ligands from the cell ${ }^{17}$ (see Fig. 4 below). Extracellular nanoparticles are

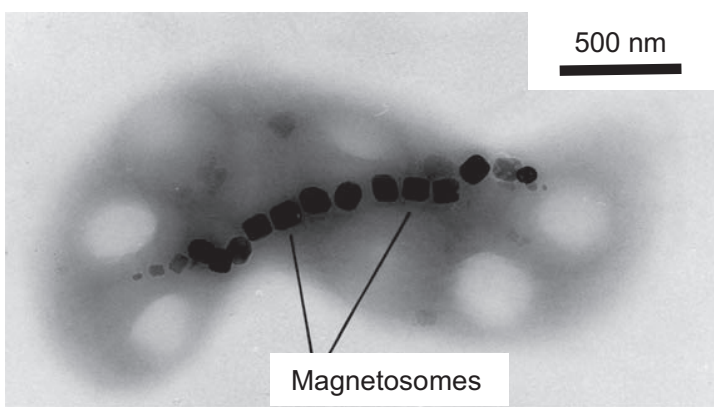

Fig. 1 Magnetosomes in a magnetotactic Spirillum species. The single magnetic domain, magnetite crystals form a chain across the bacterium and have typical elongate cuboctahedral $\{100\}+\{111\}$ habit. 
produced by bacteria in a range of natural environments and isolates hlaee Online been examined under a number of experimental conditions.

A range of oxides, phosphates, carbonates and elemental nanoparticles can be produced. Of special interest to nanotechnologists are the enzymatically controlled redox changes that result in biomineral formation which are linked to microbial respiration such as dissimilatory metal reduction. ${ }^{3}$ This latter process has been shown, for instance, to produce $\operatorname{Ag}(0)$ nanoparticles $5-40 \mu \mathrm{m}$ in $\operatorname{size}^{19,20}$ (Fig. 2), selenium/selenide/telluride nanospheres and rods ${ }^{21,22}$ (Figs. 3 and 4 ), $\mathrm{Au}(0)^{23}, \operatorname{Pd}(0)^{24}$ as well as $\mathrm{Tc}(\mathrm{IV})$ and $\mathrm{U}(\mathrm{IV})^{25}$ (see also ${ }^{26}$ for recent reviews).

The enzymatic reduction of soluble U(VI) to produce insoluble U(IV) nanoparticles and Tc (VII) to produce stable Tc(IV) are also important bioremediation pathways ${ }^{27-29}$ with potential for the clean-up of legacy contaminated soils, and relevance to the geodisposal of radwastes.

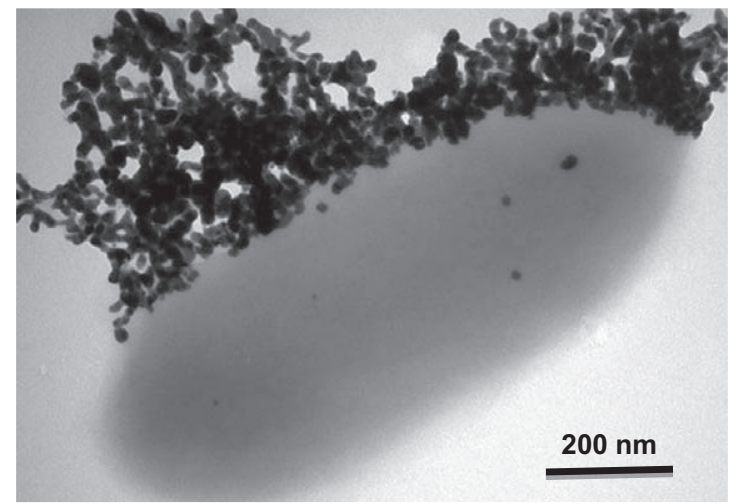

Fig. $2 \mathrm{Ag}(0)$ nanoparticles produced by enzymatic reduction of $\mathrm{Ag}(1) \mathrm{Cl}$ by Geobacter sulfurreducens (adapted from Ref. 18).

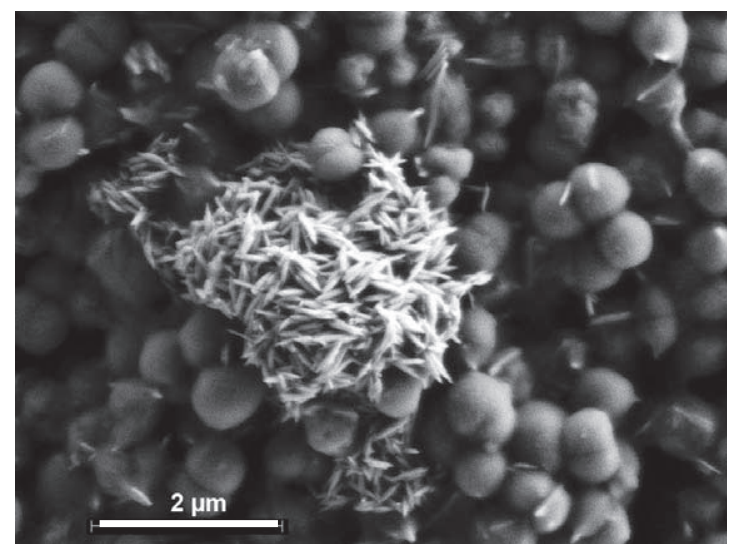

Fig. 3 Te-nanorods. Veillonella atypica cannot use Te-oxyanions as a terminal electron acceptor for anaerobic respiration but forms $\sim 100 \mathrm{~nm} \mathrm{Te}(0)$ nanorods, which can be seen protruding from the spherical cells, and as extracellular clusters, when grown under anaerobic conditions in the presence of $\mathrm{Te}(\mathrm{IV})$ at $37^{\circ} \mathrm{C}$ in a medium containing yeast extract and lactate. 


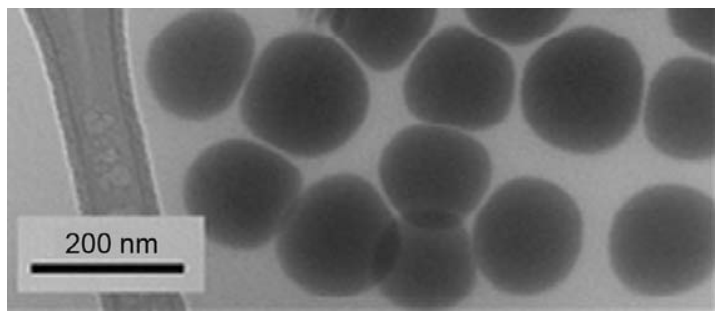

Fig. 4 Selenium nanoparticles produced by the reduction of sodium selenite by Geobacter sulfurreducens ${ }^{32}$ which can also reduce $\mathrm{Se}(\mathrm{IV})$ and Te(IV), with c-type cytochromes implicated in the electron transfer to the metalloid.

The challenge is to harness these bio-manufacturing capabilities and produce nanoparticles with tuneable properties of high enough quality and large enough quantity to challenge the environmentally more damaging, current methods of synthesis. The panacea would be the fabrication of exploitable particles from deleterious wastes, resulting in remediation with a saleable by-product; examples are the production of saleable ferrite spinels from $\mathrm{Fe}$-ferrihydroxides derived from acid mine drainage or precious metals extracted from electronic wastes. ${ }^{1}$ A further challenge is to control the chemistry of the nanoparticles. The addition of metals other than Fe into the structure of nanomagnetite $\left(\mathrm{Fe}_{3} \mathrm{O}_{4}\right)$ is well known to enhance greatly the magnetic properties of the particles, making them suitable for a range of industrial applications. ${ }^{30,31}$

\section{Exploiting extracellular biogenic magnetite}

Magnetite nanoparticles are of particular interest because of their technological value $e^{33-37}$ and they are produced by many anaerobic $\mathrm{Fe}(\mathrm{III})$-reducing bacteria found in the subsurface, where they respire the $\mathrm{Fe}(\mathrm{III})$ phase, coupling metal reduction to the oxidation of naturally occurring organic compounds or hydrogen to conserve energy for growth. ${ }^{5,27,38}$ The most intensively studied $\mathrm{Fe}(\mathrm{III})$-reducing bacteria include Geobacter and Shewanella species, although there are many other phylogentically distinct microorganisms able to respire $\mathrm{Fe}(\mathrm{III})$ minerals $^{39}$ forming nanosized magnetite $\left(\mathrm{Fe}_{3} \mathrm{O}_{4}\right)$ as a stable end-product (Fig. 5). ${ }^{40}$ Here we summarise existing work and present a new study of the substitution of $\mathrm{V}$ into bionanomagnetite and a demonstration of the effectiveness of biomagnetite in technological processes, in this case the remediation of azo dyes. The value of X-ray absorption spectroscopy (XAS) in nano-materials characterisation is also demonstrated, especially soft $\mathrm{X}$-ray analysis of the transition metal $L$-edges and X-ray magnetic circular dichroism (XMCD).

\section{Metal doped magnetites}

Over the past 5 years doped extracellular bionanomagnetite has been produced successfully in several model bacterial systems. ${ }^{41-44}$ First row transition metals $\mathrm{Co}, \mathrm{Ni}, \mathrm{Mn}, \mathrm{Cr}$ and $\mathrm{Zn}$ have all been successfully incorporated into the bionanomagnetite structure using $\mathrm{Fe}(\mathrm{III})$-reducing bacteria 

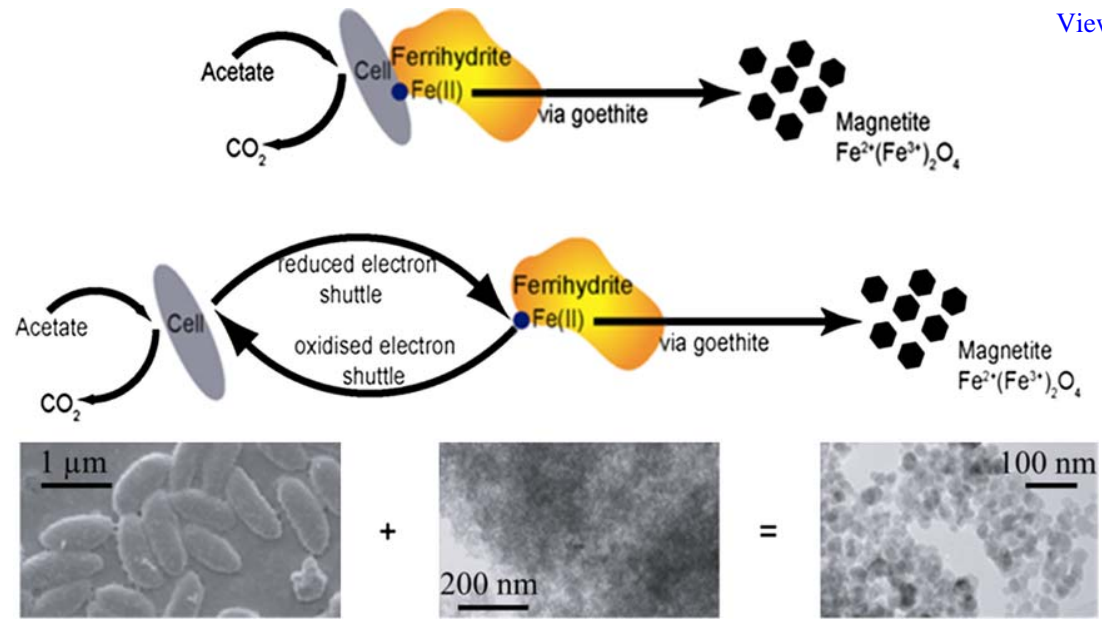

Fig. 5 The production of magnetite by the bacterium G. sulfurreducens. Cells oxidize organic substrates such as acetate to produce $\mathrm{CO}_{2}$ and directly donate electrons to the extracellular Fe(III) phase, such as schwertmannite or ferrihydrite but this requires close contact between the cell surface and the mineral phase. The rate of reduction can be increased by addition of the humic analogue anthraquinone-2,6-disulfonic acid (AQDS), which is reduced by the cells of G. sulfurreducens and acts as an electron shuttle between the cell surface and the Fe(III)-bearing mineral. The AQDS donates electrons to the Fe-hydroxyoxide, reducing $\mathrm{Fe}^{3+}$ to $\mathrm{Fe}^{2+}$. Subsequent reaction between the $\mathrm{Fe}^{2+}$ and the remaining $\mathrm{Fe}^{3+}$ results in the formation of a biogenic mixed $\mathrm{Fe}^{2+} / \mathrm{Fe}^{3+}$-bearing mineral phase (top), magnetite $\left(\mathrm{Fe}_{3} \mathrm{O}_{4}\right)$ (middle). The transmission electron micrographs reveal that the particle size of the biogenic magnetite is $\sim 30 \mathrm{~nm}$ (bottom). ${ }^{40,44}$

including G. sulfurreducens, Shewanella species and the thermophile Thermoanaerobacter ethanolis TOR-39. The precursor solid-phase used has been $\mathrm{Fe}(\mathrm{III})$-bearing minerals such as akaganeite $\left(\mathrm{Fe}^{3+} \mathrm{O}(\mathrm{OH}, \mathrm{Cl})\right)$ or ferrihydrite $\left(\mathrm{Fe}^{3+}{ }_{2} \mathrm{O}_{3} \cdot 0.5 \mathrm{H}_{2} \mathrm{O}\right)$, containing the appropriate dopant, as the electron acceptor for microbial Fe(III)-reduction ${ }^{41-54}$ (see Table 1 for details).

During bioreduction, up to one-third of the $\mathrm{Fe}$ in $\mathrm{Fe}_{3} \mathrm{O}_{4}$ has been substituted by first row transition metals resulting in significant changes in the magnetic properties of the resulting biogenic ferrite spinels. ${ }^{46,49}$ For example, G. sulfurreducens produced Co-ferrite with a magnetic coercivity at $5 \mathrm{~K}$ of $7900 \mathrm{Oe}$, compared to the equivalent 'unsubstituted' biogenic magnetite value of only $360 \mathrm{Oe}$; values equivalent to the chemically synthesized counterparts. ${ }^{46}$ Other elements have also been bio-incorporated into the spinel structure to a lesser but still significant degree. The rare earth metals including $\mathrm{Nd}, \mathrm{Gd}, \mathrm{Tb}$, Ho and $\mathrm{Er}(=\mathrm{R})$ can be included in the magnetite spinel structure using T. ethanolis TOR-39 and S. putrefaciens PV-4 to give particles with the chemical formula up to $\mathrm{R}_{0.06} \mathrm{Fe}_{2.94} \mathrm{O}_{4} \cdot{ }^{15,49,50}$ The contaminant arsenate was also found to be substituted into the magnetite spinel structure up to $1 \%$ of the total cations using G. sulfurreducens, which has implications for arsenic mobility in the subsurface. ${ }^{51}$ It should be noted that $\mathrm{Co}, \mathrm{Ni}, \mathrm{Mn}$ and $\mathrm{Zn}$ have also been incorporated into intracellularly produced magnetite by magnetotactic bacteria, however the substitution levels were much lower than those achievable using extracellular formation processes. ${ }^{14,55,56}$ 
Table 1 Production of doped bionanomagnetites.

View Online

\begin{tabular}{|c|c|c|}
\hline Dopant & Bacterium & Reference \\
\hline \multirow[t]{4}{*}{ Cobalt } & Geobacter sulfurreducens & $\begin{array}{l}\text { Coker et al., } 2008^{45} \text {; Coker et al., } \\
2009^{46}\end{array}$ \\
\hline & Shewanella oneidensis MR-1 & Coker et al., $2008^{45}$ \\
\hline & Shewanella putrefaciens $P V-4$ & $\begin{array}{l}\text { Moon et al., 2007a }{ }^{43} \text {; Moon et al., } \\
2007 \mathrm{c}^{49}\end{array}$ \\
\hline & $\begin{array}{l}\text { Thermoanaerobacter ethanolicus } \\
\text { TOR-39 }\end{array}$ & $\begin{array}{l}\text { Moon et al., } 2010 \mathrm{~b}^{50} ; \text { Roh et al., } \\
2001^{52} ; \text { Roh et al., } 2006^{52} ; \text { Moon } \\
\text { et al., } 2007 \mathrm{a}^{43} ; \text { Moon et al., } \\
2007 \mathrm{c}^{49}\end{array}$ \\
\hline \multirow[t]{5}{*}{ Nickel } & Geobacter sulfurreducens & Coker et al., $2008^{45}$ \\
\hline & Shewanella oneidensis MR-1 & Coker et al., $2008^{45}$ \\
\hline & Shewanella putrefaciens $\mathrm{CN} 32$ & Fredrickson et al., $2001^{47}$ \\
\hline & Shewanella putrefaciens $P V-4$ & $\begin{array}{l}\text { Moon et al., 2007a }{ }^{43} \text {; Moon et al., } \\
2007 \mathrm{c}^{49}\end{array}$ \\
\hline & $\begin{array}{l}\text { Thermoanaerobacter ethanolicus } \\
\text { TOR-39 }\end{array}$ & $\begin{array}{l}\text { Moon et al., } 2010 \mathrm{~b}^{50} ; \text { Roh et al. } \\
2001^{52} ; \text { Roh et al., } 2006^{51} ; \text { Moon } \\
\text { et al., 2007a } 43 \text {, Moon et al., } \\
2007 \mathrm{c}^{49}\end{array}$ \\
\hline \multirow[t]{2}{*}{ Chromium } & Shewanella putrefaciens $P V-4$ & $\begin{array}{l}\text { Moon et al., 2007a }{ }^{43} \text {; Moon et al., } \\
2007 \mathrm{c}^{49}\end{array}$ \\
\hline & $\begin{array}{l}\text { Thermoanaerobacter ethanolicus } \\
\text { TOR-39 }\end{array}$ & $\begin{array}{l}\text { Roh et al. } 2001^{52} ; \text { Roh et al., } \\
2006^{51} ; \text { Moon et al., } 2007 \mathrm{c}^{49}\end{array}$ \\
\hline \multirow[t]{3}{*}{ Manganese } & Geobacter sulfurreducens & Coker et al., $2008^{45}$ \\
\hline & Shewanella putrefaciens $P V-4$ & $\begin{array}{l}\text { Moon et al., 2007a }{ }^{43} \text {; Moon et al., } \\
2007 \mathrm{c}^{49}\end{array}$ \\
\hline & $\begin{array}{l}\text { Thermoanaerobacter ethanolicus } \\
\text { TOR-39 }\end{array}$ & $\begin{array}{l}\text { Roh et al., 2006 }{ }^{51} \text {; Moon et al., } \\
2007 \mathrm{a}^{43} ; \text { Moon et al., } 2007 \mathrm{c}^{49}\end{array}$ \\
\hline \multirow[t]{3}{*}{ Zinc } & Geobacter sulfurreducens & Coker et al., $2008^{45}$ \\
\hline & Shewanella putrefaciens $P V-4$ & $\begin{array}{l}\text { Moon et al., 2010a }{ }^{15} \text {; Moon et al., } \\
2007 \mathrm{a}^{43} \text {; Moon et al., 2007 } \mathrm{c}^{49}\end{array}$ \\
\hline & $\begin{array}{l}\text { Thermoanaerobacter ethanolicus } \\
\text { TOR-39 }\end{array}$ & 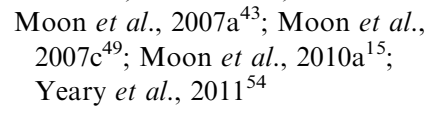 \\
\hline Manganese/Zinc & Geobacter sulfurreducens & Coker et al., $2008^{45}$ \\
\hline Arsenic & Geobacter sulfurreducens & Coker et al., $2006^{53}$ \\
\hline Vanadium & Geobacter sulfurreducens & This paper \\
\hline Rare Earths & $\begin{array}{l}\text { Thermoanaerobacter ethanolicus } \\
\text { TOR-39 }\end{array}$ & $\begin{array}{l}\text { Moon et al., 2010b }{ }^{50} \text {; Moon et al., } \\
2007 \mathrm{a}^{43} \text {; Moon et al., 2007c }{ }^{49}\end{array}$ \\
\hline
\end{tabular}

\section{X-ray magnetic circular dichroism (XMCD)}

Crucial to the understanding of metal-substituted magnetite and their properties is the determination of the site occupancy of the metals. The structure of magnetite is very well known. It is a cubic, inverse spinel with one quarter of the tetrahedral $\left(\mathrm{T}_{\mathrm{d}}\right)$ and one half of the octahedral $\left(\mathrm{O}_{\mathrm{h}}\right)$ sites filled by $\mathrm{Fe}$. The formula for magnetite is $\left(\mathrm{Fe}^{3+}\right)\left[\mathrm{Fe}^{2+} \mathrm{Fe}^{3+}\right] \mathrm{O}_{4}$ where $\mathrm{Fe}^{3+}$ 
is equally split between $\left(\mathrm{T}_{\mathrm{d}}\right)$ and $\left[\mathrm{O}_{\mathrm{h}}\right]$ sites. $\mathrm{Fe}^{2+}$ occupies only $\mathrm{O}_{\mathrm{h}}$ sities Online resulting in a distribution for stoichiometric magnetite of $1: 1: 1$ for the $\mathrm{Fe}^{2+}$ $\mathrm{O}_{\mathrm{h}}: \mathrm{Fe}^{3+} \mathrm{T}_{\mathrm{d}}: \mathrm{Fe}_{3}+\mathrm{O}_{\mathrm{h}}$ sites. The $\mathrm{Fe}^{3+}$ cations in the $\left(\mathrm{T}_{\mathrm{d}}\right)$ and $\left[\mathrm{O}_{\mathrm{h}}\right]$ sublattices have antiparallel magnetic moments that compensate each other, but there is a resulting net ferromagnetic effect due to the $\mathrm{Fe}^{2+}$ on the $\mathrm{O}_{\mathrm{h}}$ sites. The synchrotron radiation technique, X-ray magnetic circular dichroism (XMCD) has proved a powerful tool in determining the site occupancies of ferrites such as magnetite. XMCD spectra are derived from the difference between absorption spectra collected for right and left circularly polarized light, or opposite applied magnetic fields. ${ }^{57}$ It is sensitive to the oxidation state and local structure of magnetically ordered iron cations at solid surfaces. ${ }^{58}$ In magnetite the XMCD shows three distinct sharp features at the $\mathrm{Fe} L_{3}$ absorption edge which, from low to high photon energy, correspond to the $\mathrm{Fe}^{2+} \mathrm{O}_{\mathrm{h}}, \mathrm{Fe}^{3+} \mathrm{T}_{\mathrm{d}}$, and $\mathrm{Fe}^{3+} \mathrm{O}_{\mathrm{h}}$ site contributions, respectively. ${ }^{58}$ The $\mathrm{Fe}^{2+}$ and $\mathrm{Fe}^{3+}$ ions at the $\mathrm{O}_{\mathrm{h}}$ sites are aligned ferromagnetically, while coupled antiferromagnetically to the $\mathrm{Fe}^{3+}$ at the $\mathrm{T}_{\mathrm{d}}$ sites, which displays the opposite sign in the XMCD (see Fig. 6b). The relative site occupancies of $\mathrm{Fe}$ in the three sites and the effect of additional metals is then determined by quantifying the peak intensities and comparing with standard samples as well as through fitting using multiplet calculations, ${ }^{58,59}$ providing detailed information on the magnetite structure and site occupancy.

\section{Vanadium biomagnetite}

Vanadium substitution on spinel ferrites is of technological interest because it can be used to tailor the magnetic and electrical properties of the nanoparticles. It is found in nature associated with titanium-bearing magnetites and is an important source of vanadium for ferroalloys. Vanadium is toxic to higher life forms ${ }^{60}$ and anthropogenic contamination can occur via the petroleum industries because it a trace component of in fuel oils, ${ }^{61}$ and is present in certain uranium ores, thus is concentrated in former processing sites. ${ }^{61}$ Incorporation of vanadium in bionanomagnetites has not been previously examined. Many metal reducing bacteria are able to couple the reduction of vanadium $(V)$ to the oxidation of organic matter. ${ }^{5,62,63}$ In this study, a hydrous ferric oxide containing $\mathrm{V}(\mathrm{V})$ was synthesised by coprecipitation and then $\mathrm{V}$-substituted biomagnetite produced using $G$. sulfurreducens coupled to the oxidation of sodium acetate using the methods described in. ${ }^{44}$ The magnetic precipitate was characterised using transmission electron microscopy (TEM) and XMCD in order to determine the quantity, valence state and site occupancy of the Fe and V. Figure 6(a) reveals the particle size of the magnetite to be $\sim 25 \mathrm{~nm}$. XAS spectra monitored in total-electron yield (TEY) mode were collected on beamline I06 at Diamond Light Source using the portable octopole magnet system endstation. ${ }^{64}$ At each energy point the XAS was recorded for the two opposite magnetisation directions by reversing the applied field of $0.6 \mathrm{~T}$. The XAS spectra of the two magnetisation directions were normalised to the incident beam intensity and the XMCD is obtained as the difference spectrum. ${ }^{58}$ The Fe and $\mathrm{V} L_{2,3}$ XMCD gives the site occupancies and 

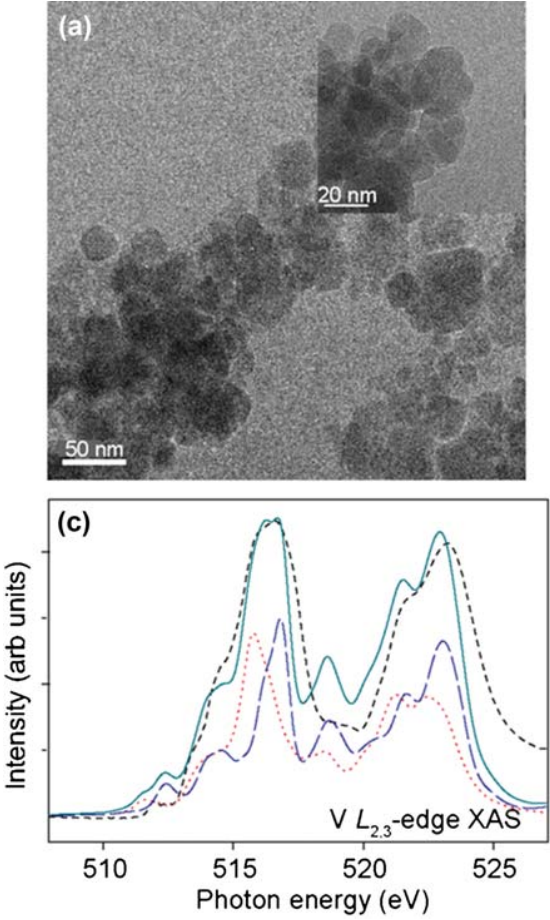
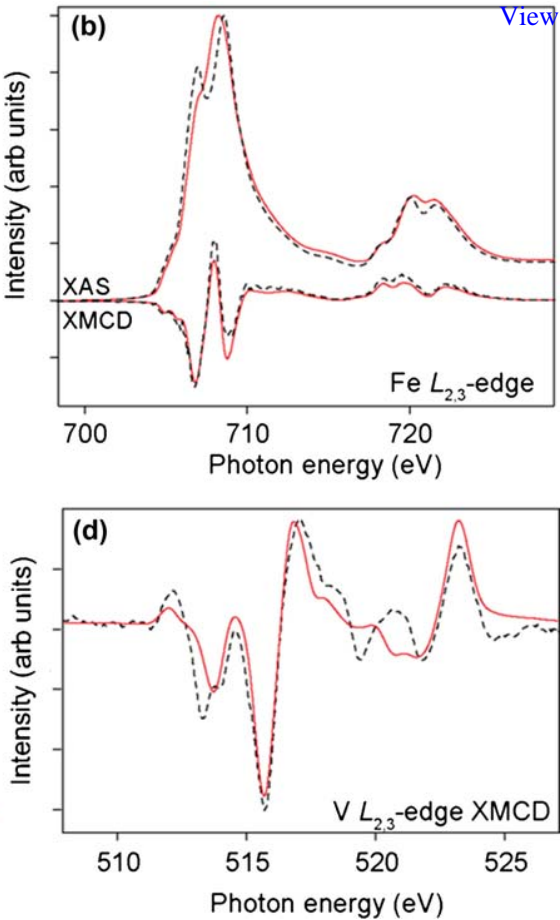

Fig. 6 Vanadium substitution in bionanomagnetite. a) Transmission electron micrographs of $10 \%$ vanadium doped magnetite; b) Fe $L_{2,3}$ XAS and corresponding XMCD spectra for biomagnetite (solid line (red)) and $10 \%$ vanadium-doped magnetite (dashed); c) calculated V $L_{2,3^{-}}$ edge XAS for V(III) (dots (red)) and V(IV) (long dashes(blue)), and V(III) + V(IV) summed in a 1:1 ratio (solid line (green)) compared with the experimental XAS (dashes(black)); d) calculated XMCD for V(III) (solid line (red)) compared with experiment (dashed (black)). The V spectra were calculated for octahedral crystal field of $10 D q=1.8 \mathrm{eV}$ in the absence of $3 d$ spin-orbit interaction.

oxidation state of the cations in the spinel structure of the magnetite, while the relative XAS intensities give the concentration ratio of the two elements. To obtain the relative amounts of $\mathrm{Fe}$ in the three coordination sites, the experimental XMCD spectra were fitted by means of a non-linear leastsquares analysis, using the calculated spectra for each of the different $\mathrm{Fe}$ sites (see ${ }^{57-59}$ for details).

Using the integrated intensities from the $\mathrm{V}$ and $\mathrm{Fe} L_{2,3} \mathrm{XAS}$, the quantity of vanadium contained in the $\mathrm{V}$-biogenic magnetite is 8.9 at $\%$ compared to iron. The shape of the Fe $L_{3}$ XAS, when compared to that for biomagnetite without vanadium (Fig. 6b), suggests that a portion of the 'non-magnetic' precursor material remains unconverted to magnetite and is represented by the prominent peak at the low energy side of the main $\mathrm{Fe} L_{3}$ peak. The Fe $L_{2,3} \mathrm{XMCD}$ of the biogenic magnetite and $\mathrm{V}$-substituted biogenic magnetite was fitted to obtain the $\mathrm{Fe}^{2+} / \mathrm{Fe}^{3+}$ ratios as 0.61 and 0.88 , respectively. This result indicates that vanadium is substituting for $\mathrm{Fe}^{3+}$. The $\mathrm{T}_{\mathrm{d}} / \mathrm{O}_{\mathrm{h}}$ ratios for biomagnetite and V-biomagnetite are 0.44 and 0.55 , respectively, indicating that the $\mathrm{Fe}^{3+}$ substitution is occurring predominantly in octahedral sites. Examination of the vanadium $L_{2,3} \mathrm{XMCD}$ and XAS spectra provides additional information. The $\mathrm{V} L_{2,3} \mathrm{XMCD}$ (Fig. 6d) shows 
an excellent agreement with the calculated spectrum for V(III), Jime Online since $\mathrm{V}_{2} \mathrm{O}_{3}$ does not contribute to the XMCD as it is antiferromagnetic (critical temperature $=160 \mathrm{~K}$ ), the presence of the XMCD confirms that $\mathrm{V}$ (III) is incorporated in the spinel structure. Comparison between the measured and calculated $\mathrm{V}_{2,3} \mathrm{XAS}^{65,66}$ indicates that, since the peaks at $516.5 \mathrm{eV}$ and $523 \mathrm{eV}$ are split, the vanadium is present in the sample both as V(III) and V(IV). The calculated XAS spectra, where the V(IV) peak has 1-2 eV higher energy than the V(III) peak, produce a good fit for $\mathrm{V}(\mathrm{III}): \mathrm{V}(\mathrm{IV})=1: 1$ (Fig. 6c) indicating that, in addition to V(III) incorporated in the ferrite spinel, a $\mathrm{VO}_{2}$ component is present. Previous work using Fe $K$-edge XAS on natural $\mathrm{V}$-bearing magnetite ${ }^{67}$ containing a few wt $\% \mathrm{~V}$, suggests the vanadium to be largely present as V(III) with less than $10 \% \mathrm{~V}$ present as V(IV). This study shows that the bacterial reduction of the doped precursor produces vanadium bionanomagnetite nanoparticles containing $8.9 \mathrm{wt} \% \mathrm{~V}$ and the combined Fe and V XMCD and XAS shows that it present as $\mathrm{V}$ (III) replacing $\mathrm{Fe}(\mathrm{III})$ predominantly in the octahedral sites. As $\mathrm{V}$ is present in soils as the bioavailable and toxic $\mathrm{V}(\mathrm{V})$ or in more reduced soils as $\mathrm{V}(\mathrm{IV})$, this incorporation in magnetite, and as $\mathrm{V}$ (III) provides a potential immobilisation and remediation pathway for contaminated sites.

\section{Bionanomagnetite in textile wastewater treatment}

The potential of bionanomagnetite in remediation of radionuclide and chromium contamination has been demonstrated ${ }^{3,27-29}$ but less has been undertaken on orgainic pollutants. Here this is addressed by the testing of the performance of bionanomagnetite to remediate azo dyes. The chromophore in reactive azo dyes consists of azo/keto-hydrazone groups as in the model reactive azo dye, Remazol Black B. Low levels of dye-fibre fixation (Fig. 7), and the presence of unreactive hydrolysed dye in the dyebath, lead to losses of up to $50 \%$ of the dye to the wastewater. These problems are compounded by the high water solubility and characteristic brightness of the dyes. Due to their stability and to their xenobiotic nature, reactive azo dyes are not totally degraded by conventional wastewater treatment processes that involve light, chemicals or activated sludge. ${ }^{68-70}$ The dyes are therefore released into the environment in the form of coloured wastewater. In this study, nanoscale schwertmannite $\left[\mathrm{Fe}^{3+}{ }_{16} \mathrm{O}_{16}(\mathrm{OH})_{12}\left(\mathrm{SO}_{4}\right)_{2}\right]$ powder was synthesized as a model $\mathrm{Fe}(\mathrm{III})$-oxide starting material. ${ }^{70}$ The schwertmannite was reduced under anaerobic conditions using G. sulfurreducens (see Fig. 5), in the presence of acetate as the electron donor. The resulting bionanomagnetite phase was isolated, washed and, along with commercially available 'abiotic' nanoscale magnetite (Johnson Matthey), exposed to Remazol Black B.

The changes in the dye were monitored by measuring the optical density at the $\lambda_{\max }$ for the dye $(597 \mathrm{~nm})$ using a UV-visible spectrophotometer. The effect of the biogenic nanomagnetite on the Remazol Black B was dramatic, revealed by the change in shape and intensity of absorption spectrum, with a major reduction in absorption over 4 days and the production of a colourless solution in 31 days that was stable to oxidation (Fig. 8). 
<smiles>COCCOCCOO</smiles><smiles>COOS(=O)(=O)c1ccc(Nc2c(O)cc3cc(O)c(NC[NH2+]c4ccc(S(=O)(=O)OCO)cc4)c(N)c3c2N)cc1</smiles>

Fig. 7 Structure of the dark blue/black reactive azo dye Remazol Black B. The azo/ketohydrazone groups can be reduced to produce the corresponding colourless amines Para Base and Diamino H-acid.
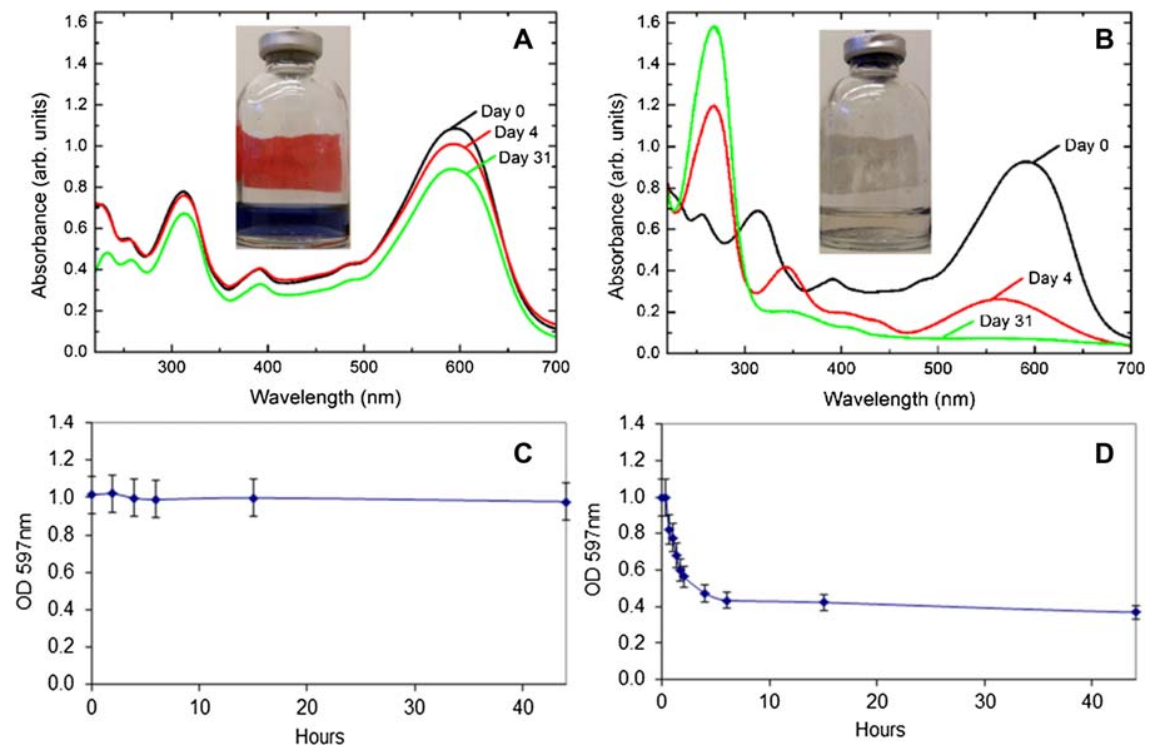

Fig. 8 Interaction of bionanomagnetite with azo dyes. UV-visible absorption spectra and inset showing colour of solution after reaction for inorganic nanomagnetite (A) and biogenic nanomagnetite (B) showing the fast and effective breakdown of the azo dye in the latter. The rate of Remazol Black $\mathrm{B}$ reduction by inorganic nanomagnetite $(\mathrm{C})$ and biogenic nanomagnetite (D) is revealed graphically by monitoring the absorption at $597 \mathrm{~nm}$.

The bionanomagetite had totally reduced the azo chromophore in the dye to form the corresponding colourless amines. Commercially available abiotic magnetite adsorbed the dye, resulting in a slight reduction in intensity but no change in shape of the absorption spectrum and the solution remained distinctly blue.

Both bionanomagnetite and abiotic nanomagnetite were analysed, before and after dye reduction using XMCD (Fig. 9) and show that the $\mathrm{Fe}^{2+} / \mathrm{Fe}^{3+}$ ratio at the surface of the abiotic nanomagnetite did not change during the experiment, but the biogenic nanomagnetite showed a decrease in the amount of $\mathrm{Fe}^{2+}$, indicating the $\mathrm{Fe}^{2+}$ was oxidized concurrent with the reduction of Remazol Black B. However, a substantial 

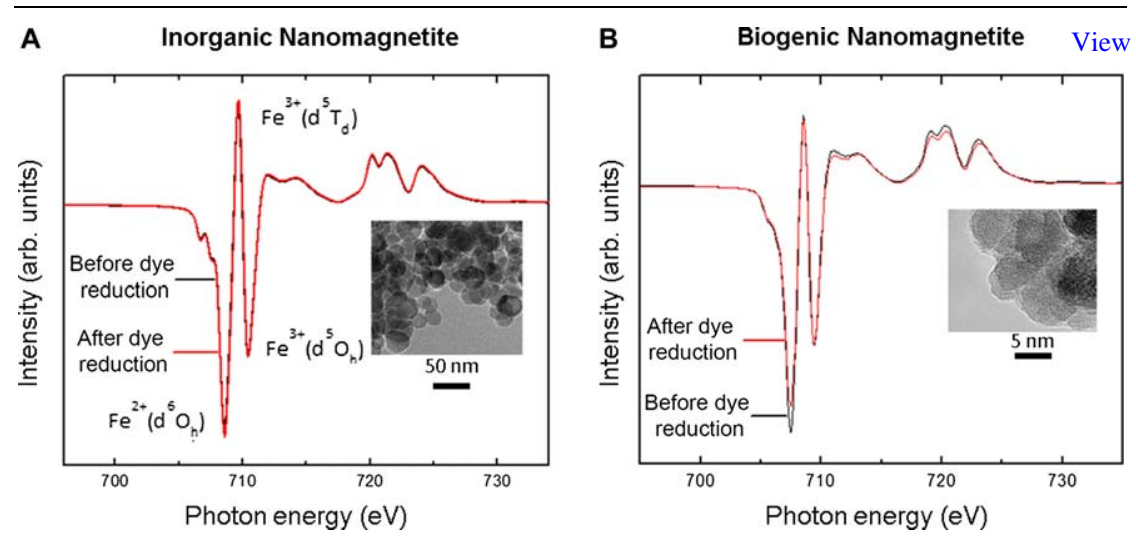

Fig. 9 XMCD spectra of bionanomagnetite before and after interaction with the azo dye. (A) shows the XMCD spectra (inset showing TEM image of the nanoparticles) for inorganic magnetite and (B) for biogenic nanomagnetite. The latter shows reduction of the octahedral $\mathrm{Fe}^{2+}$ component, as indicated (black curves are before interaction, grey (red) curves are after interaction).

amount of $\mathrm{Fe}^{2+}$ remained at the surface of the biogenic nanomagnetite after the reductive transformation, presenting the opportunity for recycling the material.

\section{Conclusions}

This review outlines some recent advances in our understanding of the bioproduction of fucntional nanoparticles. Although focusing on the tunable bioproduction of nano-scale extacellular magentite, this work should be seen in the context of recent dramatic advances in the microbial fabrication of a far wider range of functional nanomaterials, reviewed in, ${ }^{3}$ and extended recently to form a new area of synthetic biology. ${ }^{71}$ To date much of this work has been done at the laboratory scale, producing mg quantities of material, and successful scale-up is now an important priority. This has been achieved for $\mathrm{Zn}$-substituted biomagnetite using T. ethanolis TOR-39 in a fermenter (30 L/1 kg dry weight magnetite), ${ }^{15}$ and more recently by this group using both Shewanella and Geobacter species at a similar scale. Many challenges remain. For those working with intracellular bacterial magnetosomes the particles produced are consistent in size and shape and the challenge is volume of production, while for extracellular bacterial nanoparticles, volumes are already achievable but particle homogenity and narrower size ranges are the challenge. New metagenomic strategies to identify magnetosome genes with potential templating techniques may lead to high value specialised nanoparticles from magnetotactic bacteria. ${ }^{72-75}$ Production of extracellular nanoparticles will tap into the enormous range and diversity of biomineralising bacterial species and their high productivity, adaptability and tunability; these are likely to produce materials for less specialised applications and bioremediation.

\section{Acknowledgements}

The authors are grateful to support from an EPSRC collaborative research fund to support this work. Portions of this work were performed at the 
Molecular Foundry and Beamline 4.0.2 at the Advanced Light Source, bbekr Online part of the Lawrence Berkeley National Laboratory, which is supported by the Office of Science, Office of Basic Energy Sciences, US Department of Energy, under contract no. DE-AC02-05CH11231, with special thanks to Ron Zuckermann (Biological Nanostructures Facility) and Elke Arenholz (ALS). XMCD measurements were also undertaken on beamline I06 at the Diamond Light Source, Didcot, Oxfordshire, UK and the beamline staff are thanked for their generous support. The magnetite for the azo dye experiment was prepared by Richard Cutting, SEAES, University of Manchester, UK.

\section{References}

1 J. R. Lloyd, C. I. Pearce, V. S. Coker, R. A. D. Pattrick, G. van der Laan, R. Cutting, D. J. Vaughan, M. Paterson-Beedle, I. P. Mikheenko, P. Yong and L. E. Macaskie, Geobiology, 2008, 6, 285.

2 L. E. Macaskie, I. P. Mikheenko, P. Yong, K. Deplanche, A. J. Murray, M. Paterson-Beedle, V. S. Coker, C. I. Pearce, R. A. D. Pattrick, D. J. Vaughan, G. van der Laan and J. R. Lloyd, Advanced Materials Research, 2009, 71-73, 541.

3 J. R. Lloyd, J. M. Byrne and V. S. Coker, Current opinion in biotechnology, 2011, 22, 509 .

4 D. R. Lovley, D. E. Holmes and K. P. Nevin, Advances in Microbial Physiology, 2004, 49, 219.

5 J. R. Lloyd, FEMS Microbiology Reviews, 2003, 27, 411.

6 C. D. Bazylinski and R. B. Frankel, Rev. in Min. and Geochem., Amer. Mineral. Soc., 2003, 54, 217.

7 T. L. Kieft, J. K. Fredrickson, T. C. Onstott, Y. A. Gorby, H. M. Kostandarithes, T. J. Bailey, D. W. Kennedy, S. W. Li, A. W. Plymale, C. M. Spandoni and M. S. Gray, Appl. Env. Microbiol., 1999, 65, 1214.

8 F. Wolfe-Simon, J. S. Blum, T. R. Kulp, G. W. Gordon, S. E. Hoeft, J. Pett-Ridge, J. F. Stolz, S. M. Webb, P. K. Weber, P. C. W. Dabies, A. D. Anbar and R. S. Oremland, Science, 2011, 332, 1163.

9 M. Posfai, P. R. Buseck, D. A. Bazylinski and R. B. Frankel, Amer. Mineral., 1998, 83, 1469.

10 T. Kasama, M. Posfai, R. K. K. Chong, A. P. Finlayson, R. E. DuninBorkowskib and R. B. Frankel, Physica B, 2006, 384, 249.

11 B. Devouard, M. Posfai, H. Xin, D. A. Bazylinski, R. B. Frankel and P. R. Buseck, Amer. Mineral. 83, 1387.

12 B. M. Moskowitz, Reviews of Geophysics, 1995, 33, 123.

13 S. Lang, D. Schüler and D. Faivre, Macromolecular Bioscience, Special Issue: Bioinspired Materials, 2007, 7, 144.

14 S. S. Staniland, W. Williams, N. D. Telling, G. van der Laan, A. Harrison and B. Ward, Nature Nanotechnol., 2008, 3, 158.

15 J.-W. Moon, C. J. Rawn, A. J Rondinone, L. J. Love, Y. Roh, S. M. Everett, R. J. Lauf and T. J. Phelps, J. Ind. Microbiol. \& Biotech., 2010a, 37, 1023.

16 H. L. Ehrlich, Geomicrobiology, 1996, 3rd Ed. Marcel Dekker, Inc., New York.

17 K. Konhauser, Introduction to Geomicrobiology, Blackwell Publishing, Malden, MA, 2007.

18 N. Law, S. Ansari, F. R. Livens, J. C. Renshaw and J. R. Lloyd, Appl. Environ. Microbiol., 2008, 74, 7090.

19 T. Klaus-Joerger, R. Joerger, E. Olsson and C. G. Granqvist, Trends in Biotechnol., 2001, 19, 15. 
20 S. Mann, Biomineralization, Principles and Concepts in Bioinorganic Materitury Online Chemistry, 2001, Oxford University Press.

21 C. I. Pearce, V. S. Coker, J. M. Charnock, R. A. D. Pattrick, J. F. W. Mosselmans, N. Law, T. J. Beveridge and J. R. Lloyd, Nanotechnology, 2008, 19, 155603.

22 J. Dobias, E. I. Suvorova and R. Bernier-Latmani, Nanotechnology, 2011, 22, 195605.

23 S. He, Z. Guo, Y. Zhang, S. Zhang, J. Wang and N. Gu, Materials, 2007, 61, 3984.

24 J. R. Lloyd, V. A. Sole, C. V. Van Praagh and D. R. Lovely, Appl. Environ. Microbiol., 2000, 66, 3743.

25 J. R. Lloyd, FEMS Microbiology Reviews, 2003, 27, 411.

26 M. Rai and N. Duran (Eds), Metal nanoparticles in microbiology, 2011, Springer.

27 D. R. Lovely, Microbiol Rev, 1991, 55, 259.

28 Y. Suzuki, S. D. Kelly, K. M. Kemner and J. F. Banfield, Nature, 2002, 419, 134.

29 J. C. Renshaw, L. J. C. Butchins, F. R. Livens, I. May, J. M. Charnock and J. R. Lloyd, Environ. Sci. Technol., 2005, 39, 5657.

30 D.-H. Kim, D. E. Nikles, D. T. Johnson and C. S. Brazel, J Magn. Magn. Mater., 2008, 320, 2390.

31 S. Sun, H. Zeng, D. B. Robinson, S. Raoux, P. M. Rice, S. X. Wang and G. Li, J. Am. Chem. Soc., 2004, 126, 273.

32 C. I. Pearce, R. A. D. Pattrick, N. Law, J. M. Charnock, V. S. Coker, J. W. Fellowes, R. S. Oremland and J. R. Lloyd, Environmental technology, 2009, 30, 1313.

33 C. Alexiou, R. Jurgons, C. Seliger and H. Iro., J. Nanosci. Nanotech., 2007, 6, 2762.

34 D. E. Crean, V. S. Coker, G. van der Laan and J. R. Lloyd, Env. Sci. Tech., 2012, 46, 3352.

35 G. F. Goya, T. S. Berquo, F. C. Fonseca and M. P. Morales, J. Appl. Phys., 2003, 94, 3520 .

36 V. Hencl, P. Mucha, A. Orlikova and D. Leskova, Wat. Res., 1995, 29, 383.

37 T. Matsunaga, Y. Okamura and T. Tanaka, J. Mater. Chem., 2004, 14, 2099.

38 F. Jr. Caccavo, D. J. Lonergan, D. R. Lovley, M. Davis, J. F. Stolz and M. J. McInerney., Appl. Environ. Microbiol., 1994, 60, 3752.

39 D. R. Lovely, D. E. Holmes and K. P. Nevin, Advances in Microbial Physiology, 2004, 49, 219.

40 R. S. Cutting, V. S. Coker, J. W. Fellowes, J. R. Lloyd and D. J. Vaughan, Geochim. Cosmochim. Acta, 2003, 73, 4004.

41 V. S. Coker, R. A. D. Pattrick, G. van der Laan and J. R. Lloyd, In Magnetoreception and magnetosomes in bacteria, D Schüler, ed, Microbiol Monogr, 2006, 3 , 1 .

42 V. S. Coker, C. I. Pearce, C. Lang, G. van der Laan, R. A. D. Pattrick, N. D. Telling, D. Schüler, E. Arenholz and J. R. Lloyd, Eur J. Mineral, 2007, 19, 707-16.

43 J.-W. Moon, Y. Roh, R. J. Lauf, H. Vali, L. W. Yeary and T. J. Phelps, J. Microbial. Methods, 2007a, 70, 150.

44 V. S. Coker, A. M. T. Bell, C. I. Pearce, R. A. D. Pattrick, G. van der Laan and J. R. Lloyd, Amer. Mineral., 2008, 93, 540.

45 V. S. Coker, C. I. Pearce, R.A.D Pattrick, G. van der Laan, N. D. Telling, J. M. Charnock, E. Arenholz and J. R. Lloyd, Amer. Mineral., 2008, 93, 1119.

46 V. S. Coker, N. D. Telling, G. van der Laan, R. A. D. Pattrick, C. I. Pearce, E. Arenholz, F. Tuna, R. E. P. Winpenny and J. R. Lloyd, ACS Nano, 2009, 3, 1922.

47 J. K. Fredrickson, J. M. Zachara, R. K. Kukkadapu, Y. A. Gorby, S. C. Smith and C. F. Brown, Environ. Sci. Technol., 2001, 35, 703. 
48 J.-W. Moon, Y. Roh, L. W. Yeary, R. J. Lauf, C. J. Rawn, L. J. Love and Tịp̣ Online Phelps, Extremophiles, 2007b, 11, 859.

49 J.-W. Moon, L. W. Yeary, A. J. Rondinone, C. J. Rawn, M. J. Kirkham, Y. Roh, L. J. Love and T. J. Phelps, J. Magn. Magn. Mater., 2007c, 313, 283.

50 J.-W. Moon, C. J. Rawn, A. J. Rondinone, W. Wang, H. Vali, L. W. Yeary, L. J. Love, M. J. Kirkham, B. Gu and T. J. Phelps, J. Nanosci. Nanotech., 2010b, 10, 8298.

51 Y. Roh, H. Vali, T. J. Phelps and J.-W. Moon., J. Nanosci. Nanotech., 2006, 6, 3517.

52 Y. Roh, R. J. Lauf, A. D. McMillan, C. Zhang, C. J. Rawn, J. Bai and T. J. Phelps, Solid State Communications, 2001, 118, 529.

53 V. S. Coker, A. G. Gault, C. I. Pearce, G. van der Laan, N. D. Telling, J. M. Charnock, D. A. Polya and J.R Lloyd, Environ. Sci. Technol., 2006, 40, 7745.

54 L. W. Yeary, J.-W. Moon, C. J. Rawn, L. J. Love, A. J. Rondinone, J. R. Thompson, B. C. Chakoumakos and T. J. Phelps. J. Magnetism and Magnetic Materials, 2011, 323, 3043.

55 C. N. Keim, U. Lins and M. Farina, FEMS Microbiology Letters, 2009, 292, 250.

56 S. Kundu, A. A. Kale, A. G. Banpurkar, G. R. Kulkarni and S. B. Ogale, Biomaterials, 2009, 30, 4211.

57 G. van der Laan and B. T. Thole, Phys. Rev. B, 1991, 43, 13401.

58 R. A. D. Pattrick, G. van der Laan, C. M. B. Henderson, P. Kuiper, E. Dudzik and D. J. Vaughan, Eur. J, Mineral., 2002, 14, 1095.

59 G. van der Laan and I. W. Kirkman, J. Phys. Condensed Matter, 1992, 4, 4189.

60 B. A. Rattner, M. A. McKernan, K. M. Eisenreich, W. A. Link, G. H. Olsen, D. J. Hoffman, K. A. Knowles and P. C. McGowan., J. Toxicol. Environ. Health A, 2006, 69, 331.

61 U. S. Department of Energy Doc. No. S06654, 2010.

62 I. R. T. Ortiz-Bernad, R. T. Anderson, H. A Vrionis and D. R. Lovley, Applied and Environ. Microbiol., 2004, 70, 3091.

63 D. R. Lovley, Ann. Rev. Microbiol, 1993, 47, 263.

64 N. D. Telling, 2007, unpublished.

65 M. G. Brik, K. Ogasawara, H. Ikeno and I. Tanaka, Eur. Phys. J. B, 2006, 51, 345.

66 J.-S. Kang, J. Hwang, D. H. Kim, E. Lee, W. C. Kim, C. S. Kim, S. Kwon, S. Lee, J.-Y. Lee, T. Ureno, B. T. Sawada and B. H. Kim, Phys. Rev. B, 2012, 85, 165136.

67 E. Balan, J. P. R. De Villiers, S. G. Eeckhout, P. Glatzel, M. J. Toplis, E. Fritsch, T. Allard, L. Galoisy and G. Calas, Amer. Mineral., 2006, 91, 953.

68 T. Leisinger, R. Hutter, A. M. Cook and J. Nuesch, FEMS symposium no. 12., 1981, Academic Press.

69 C. I. Pearce, J. R. Lloyd and J. T. Guthrie, Dyes and Pigments, 2003, 58, 179.

70 R. S. Cutting, V. S. Coker, R. L. Kimber, D. J. Vaughan and J. R. Lloyd, Environ Sci Technol., 2010, 44, 2577.

71 J. M. Foulkes, K. J. Malone, M. Harfouche, N. J. Turner and J. R. Lloyd, ACS Catalysis, 2011, 1, 1589.

72 C. Jogler, M. Niebler, W. Lin, M. Kube, G. Wanner, S. Kolinko, P. Stief, A. J. Beck, D. de Beer, N. Petersen, Y. Pan, R. Amann, R. Reinhardt and D. Schüler, Environmental Microbiology, 2010, 12, 2466.

73 H. Wang, Y. Yu, Y. Sun and Q. Chen, Nano, 2011, 6, 1.

74 J. M. Galloway, J. P. Bramble, A. E. Rawlings, S. D. Evans and S. S. Staniland, J. Nano Research, 2012, 17, 127.

75 C. Jogler and D. Schüler, Annual Rev. Microbiol., 2009, 63, 501. 